\title{
PENGARUH CURRENT RATIO DAN QUICK RATIO TERHADAP PERUBAHAN LABA PADA PT. AKASHA WIRA INTERNASIONAL TBK
}

\author{
${ }^{a}$ Anti Febi Insan, blta Purnama \\ ${ }^{a b}$ Sekolah Tinggi IImu Ekonomi Bima \\ antifebi17stiebima.@gmail.com
}

\begin{abstract}
This study aims to determine the effect of liquidity ratios on changes in earnings at $P T$ Akasha Wira Internasional Tbk listed on the Indonesian stock exchange (BEI). In this study, the company's liquidity ratio is measured by the Curren ratio and the Quick Ratio. The population in this study is the company PT. Akasha Wira Internasional Tbk which was listed on the Indonesia Stock Exchange during the 2006-2019 period. The sample of this study was used 10 years starting from 2010-2019 taken using purposive sampling method. data analysis used to test the hypothesis is to use multiple linear regression analysis techniques. From the research results, it was found that the results of the test partially Current Ratio had no effect on changes in earnings as evidenced by a significant value of $0.678>0.05$, while the significant value of the Quick Ratio was $0.222>0.05$. This proves that the current ratio and quick ratio have no significant effect on changes in earnings. it can be concluded that the current ratio and quick ratio simultaneously do not have a significant effect on changes in earnings. The results of this study are in line with Gunawan and Wahyuni (2013).
\end{abstract}

Keywords: Current Ratio, Quick Ratio, Profit Changes

\begin{abstract}
ABSTRAK
Penelitian ini bertujuan untuk mengetahui pengaruh rasio likuiditas terhadap perubahan laba pada perusahaan PT.Akasha Wira Internasional Tbk yang terdaftar di bursa efek Indonesia (BEI). Dalam penelitian ini rasio likuiditas perusahaan diukur dengan Curren ratio dan Quick ratio. Populasi dalam penelitian ini adalah perusahaan PT. Akasha Wira Internasional Tbk yang terdaftar di Bursa Efek Indonesia selama periode 2006-2019. Sampel penelitian ini digunakan 10 tahun mulai dari 2010-2019 diambil dengan menggunakan metode purposive sampling. analisis data yang digunakan untuk menguji hipotesis adalah dengan menggunakan teknik analisis regresi linear berganda. Dari hasil penelitian ditemukan bahwa hasil uji $t$ secara parsial Current Ratio tidak berpengaruh terhadap perubahan laba dibuktikan dengan nilai signifikan sebesar 0,678 > 0,05 sedangkan Quick Ratio nilai signifikannya sebesar 0,222 > 0,05. hal ini membuktikan bahwa current ratio dan quick ratio secara signifikan tidak berpengaruh terhadap perubahan laba. maka dapat disimpulakan secara simultan current ratio dan quick ratio tidak berpengaruh signifikan terhadap perubahan laba.hasil penelitian ini sejalan dengan Gunawan dan Wahyuni (2013).
\end{abstract}

Kata Kunci : Current Ratio, Quick Ratio, Perubahan Laba 


\section{PENDAHULUAN}

Dalam pertumbuhan kegiatan usaha yang berkembang pesat saat ini, bagian keuangan merupakan salah satu bagian terpenting yang dapat meyebabkan kondisi perekonomian menjadi tidak stabil sehingga beberapa perusahaan dapat mengalami kebangkrutan. Jika perusahaan ingin mempertahankan diri dan dapat berkembang dengan baik,maka perusahaan harus mengetahui kondisi serta kinerja perusahaan tersebut. pertumbuhan kinerja yang baik dapat menambah manfaat bagi perusahaan, dimana hal tersebut memikat investor dalam menanamkan modal pada perusahaan dengan harapan perusahaan dapat bertumbuh kembang dengan baik agar dapat memperoleh laba yang optimal. Laba adalah peningkatan kekayaan seseorang investor sebagai hasil dari penanaman modal setelah dikurangi biaya-biaya terkait penanaman modal tersebut.maka dari itu perubahan laba merupakan kenaikan atau penurunan laba per tahun. Perubahan laba yang tinggi mengindikasikan laba yang diperoleh perusahaan tinggi, sehingga tingkat pembagian deviden perusahaan tinggi pula. Maka dari itu, perubahan laba akan memengaruhi keputusan investasi para investor yang akan menanamkan modalnya ke dalam perusahaan.

Adapun teknik analisis yang sering digunakan dalam menganalis laporan keuangan adalah dengan menggunakan analisis rasio keuangan.rasio keuangan sering digunakan untuk mengukur kekuatan atau kelemahan yang dihadapi perusahaan dibidang keuangan,selain itu, rasio keuangan dapat dipakai sebagai sistem peringatan awal terhadap kemunduran dari suatu perusahaan (sa'diyah dan kemaurawana ,2015).dan rasio yang digunakan untuk menilai kinerja keuangan perusahaan yaitu rasio likuiditas. Rasio likuiditas bertujuan untuk mengetahui kemampuan perusahaan dalam membayar atau memenuhi kewajiban jangka pendek dengan tepat waktu.rasio likuiditas yang digunakan dalam penelitian ini adalah current ratio dan quick ratio.menurut (kasmir, 2017:135) Current ratio merupakan rasio yang digunakan untuk mengukur kemampuan perusahaan dalam membayar kewajiban jangka pendek atau utang yang segera jatuh tempo pada saat ditagih keseluruhan . Menurut Herry (2015:178) Quick ratio merupakan rasio untuk mengukur sejauh mana kemampuan perusahaan membayar kewajiban jangka pendeknya atau kewajiban yang sudah jatuh tempo dengan menggunakan aset lancar yang tersedia.

Pt. Akasha Wira Internasional Tbk adalah perusahaan yang bergerak di bidang produksi air minum dalam kemasan, distribusi produk kosmetik dan perdagangan besar dan perusahaan ini berdiri sejak tahun 1985. Disetiap perusahaan pasti ada terjadi kenaikan atau turun nya suatu laba yang dihasilakan. Maka Berikut tabel perubahan laba pada PT. Akasha Wira Internasional Tbk tahun 2010-2019.

Tabel. Laba Perusahaan PT. Akasha Wira Internasional Tbk. Dari tahun 2010-2019 (Dalam Jutaan Rupiah)

\begin{tabular}{|c|c|}
\hline TAHUN & LABA \\
\hline 2010 & $\begin{array}{c}\text { RP. } \\
8,132\end{array}$ \\
\hline 2011 & $\begin{array}{c}R P . \\
25,868\end{array}$ \\
\hline 2012 & $\begin{array}{c}\mathrm{RP} . \\
83,376\end{array}$ \\
\hline 2013 & $\begin{array}{c}\text { RP. } \\
55,656\end{array}$ \\
\hline 2014 & $\begin{array}{c}\text { RP. } \\
31,021\end{array}$ \\
\hline
\end{tabular}




\begin{tabular}{|c|c|}
\hline 2015 & $\begin{array}{c}\text { RP. } \\
32,839\end{array}$ \\
\hline 2016 & $\begin{array}{c}\text { RP. } \\
55,951\end{array}$ \\
\hline 2017 & $\begin{array}{c}\mathrm{RP} . \\
38,242\end{array}$ \\
\hline 2018 & $\begin{array}{c}\text { RP. } \\
83,885\end{array}$ \\
\hline 2019 & $\begin{array}{c}\text { RP. } \\
52,958\end{array}$ \\
\hline
\end{tabular}

Berdasarkan laporan keuangan dari PT. Akasha Wira Internasional Tbk, perusahaan mengalami fluktuatif dari hasil 10 tahun terakhir. yang dapat dilihat dari laporan keuangan PT. Akasha Wirsa Internasional Tbk pada tahun 2010 sebesar Rp. 8.132 dan tahun 2011 terjadi kenaikan laba sebesar Rp. 25.868 dan ditahun 2012 laba yang dihasilakn cukup baik sebesar Rp. 83.376 dan pada tahun 2013-2017 laba yang didapatkan terjadinya kenaikan dan penurunan yang tidak stabil terhadap perusahaan PT. Akasha Wira Internasional dan tahun 2018 terjadi kenaikan yang cukup baik dalam perusahaan sebesar Rp. 83.885 dimana tahun 2019 terjadi penurunan kembali sebersar Rp. 52.958. Jelas terlihat pada perushaan PT. Akasha Wira Internasional Tbk mengalami peningkatan dan penurunan (fluktuatif) dari tahun sebelum dan sesudah yang signifikan terhadap perusahaan. Dari hasil laporan keuangan menunjukan bahwa perusahaan belum mampu memaksimalkan laba dengan menggunakan modal sendiri disetiap tahunnya dan hal ini disebabkan karena ketidakmampuan membayar kewajiban lancarnya dengan menggunakan aset lancar tanpa persediaan dan hal ini menyebabkan perusahaan mengalami penurunan laba atau bahkan mengalami kerugian.

\section{LANDASAN TEORI}

\section{a.) Current Ratio (CR)}

Menurut hanafi dan halim (2012:75) current ratio merupakan kemampuan perusahaan memenuhi hutang jangka pendeknya dengan menggunakan aktiva lancar .menurut Fahmi (2012:121),current ratio adalah ukuran yang umum digunakan atas solvensi jangka pendek,kebutuhan suatu perusahaan memenuhi utang yang sudah jatuh tempo. Rumus untuk mencari current ratio sebagai berikut :

$$
\text { Current Ratio }(C R)=\frac{\text { Aset Lancar }}{\text { hutang lancar }}
$$

\section{b.) Quick Ratio (CR)}

Quick Ratio menurut Fahmi (2012:125), merupakan ukuran uji solvensi jangka pendek yang lebih teliti daripada rasio lancar. Merurut Riana (2016) Quick Ratio menunjukkan kemampuan aset lancar yang paling likuid untuk melunasi utang lancar, karena membandingkan antara jumlah aset lancar dikurangi persediaan dengan jumlah utang lancar. Rumus untuk mencari Quick Ratio sebagai berikut :

$$
\text { Quick Ratio }(Q R)=\frac{\text { Aset Lancar }- \text { persediaan }}{\text { hutang lancar }}
$$




\section{c.) Perubahan Laba}

Salvatore (dalam Septiawan,2014:24) menyatakan bahwa perubahan laba merupakan kenaikan atau penurunan laba per tahun. Laba yang tinggi merupakan tanda bahwa konsumen menginginkan output industri lebih banyak. Laba yang tinggi memberikan insentif bagi perusahaan untuk meningkatkan output dan lebih banyak perusahaan yang akan masuk ke industri tersebut dalam jangka panjang. Laba yang lebih rendah atau kerugian merupakan tanda bahwa konsumen menginginkan komoditas lebih sedikit atau metode produksi perusahaan tersebut tidak efisien.

Sedangkan menurut harahap (2015:310), perubahan laba merupakan rasio yang menunujukan kemampuan perusahaan meningkatkan laba bersih disbanding tahun sebelumnya.Rumus untuk mencari perubahan laba sebagai berikut :

$$
\Delta Y t=\frac{(Y t-Y t-1)}{Y t-1}
$$

\section{d.) Hipotesis}

Hipotesis adalah jawaban sementara terhadap masalah yang masih bersifat praduga karena masih dibuktikan kebenarnnya. Maka hipotesis yang dapat diuji sebagai berikut :

1. $\mathrm{H} 1=$ Current ratio secara parsial berpengaruh terhadap perubahan laba

2. $\mathrm{H} 2=$ Quick ratio secara parsial berpengaruh terhadap perubahan laba

3. $\mathrm{H} 3=$ Current ratio dan quick ratio secara simultan berpengaruh terhadap perubahan laba

\section{METODE PENELITIAN}

Pada penelitian ini digunakan jenis penelitian asosiatif dimana menurut (Sugiyono, 2016) penelitiain asosiatif yaitu suatu penelitian yang bersifat mengetahui pengaruh antara dua variabel atau lebih yaitu pengaruh variabel $x$ (current ration $(x 1)$ dan quick ratio $(x 2)$ ) terhadap variabel $y$ (perubahan laba). Lokasi tempat penelitian PT. Akasha Wira Internasional Tbk yang beralamatkan di : Perkantoran Hijau Arkadia, Tower C, Lt. 15, Jalan Tb Simatupang No.88, RT.1/RW.1, Kebagusan, Kec. Ps. Minggu, Kota Jakarta Selatan, Daerah Khusus lbukota Jakarta 12520. Melalui website ini https://www.akashainternational.com/id ID/financial-report/. Teknik analisis data yang digunakan dalam penelitian ini yaitu analisis regresi linear berganda. Adapun teknik pengumpulan data pada penelitian ini yaitu studi pustaka adalah alat pengumpulan data dengan adanya studi pustaka yang berkaitan dengan objek peneliti, dan dokumentasi yang merupakan pencatatan dan pengumpulan dari berbagai dokumen yang memperkuat analisis data penelitian dengan meneliti data-data yang ada kaitannya dengan objek penelitian.dan Sumber data yang digunakan pada penelitian ini adalah data sekunder seperti artikel, jurnal-jurnal serta situs internet yang berkaitan dengan penelitian yang dilakukan dan website resmi pada PT. Akasha Wira Internasional Tbk bursa efek Indonesia yang sudah tersedia dalam laporan keuangan melalui websiteini. https://www.akashainternational.com/id ID/financial-report/. Populasi yang digunakan dalam penelitian ini adalah data laporan keuangan yang terdaftar Dibursa Efek Indonesia selama 14 tahun dari (2006-2019) dan sampel yang digunakan dalam penelitian ini selama 10 tahun dari tahun (2010-2019) dengan menggunakan teknik purposive sampling yang memnuhi kriteria untuk penelitian ini. Adapun teknik analisis data yang digunakan untuk mengelola data dalam penelitian ini adalah : uji asumsi klasik, uji normalitas, uji multikolineritas, uji autokorelasi, uji heteroskedastisitas, uji regresi linear berganda dan uji hipotesis. 
1. Uji Asumsi Klasik

a. Uji Normalitas

Menurut sugiono (2011:149) Uji normalitas bertujuan untuk menguji apakah dalam model regresi, variabel pengganggu atau residual memiliki distribusi normal. Dalam uji ini akan menggunakan tabel Kolmogorov-Smirnov dengan menggunakan taraf signifikan sebesar 0,05 atau $5 \%$ dan menggunakan grafik normal plot dibawah ini :

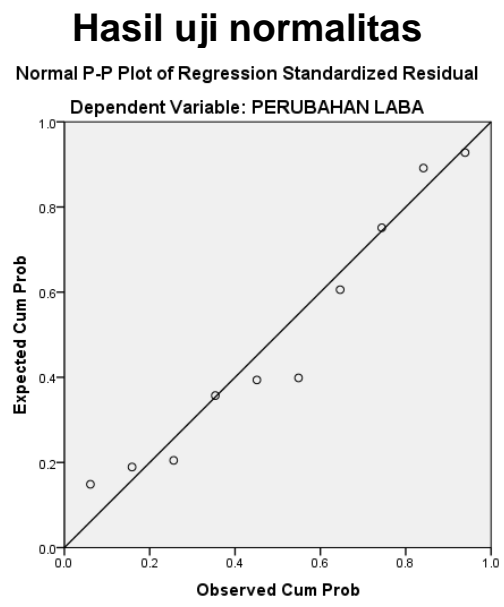

Berdasarkan hasil gambar spss diatas pada titik-titik tersebut mengikuti garis diagonal maka kesimpulannya Uji normalitas model regresi berdistribusi normal. Dapat disimpulkan bahwa melalui pendekatan Kolmogorov-Smirnov maupun pendekatan grafik, telah memenuhi asumsi normalitas.

\section{b. Uji Multikolineritas}

Ghozali (2016:103) mengemukakan bahwa uji multikolinieritas bertujuan untuk menguji apakah model regresi ditemukan adanya korelasi antar variabel bebas (independen). Model regresi yang baik seharusnya tidak terjadi korelasi di antara independen. Korelasi antara variabel bebas dapat di deteksi apabila mempunyai nilai VIF lebih kecil dari 10 dan mempunyai angka tolerance kurang dari 0,10 .

Tabel 1

Hasil uji multikolineritas

\section{Coefficients $^{\mathrm{a}}$}

\begin{tabular}{|c|c|c|c|c|c|c|c|c|}
\hline \multirow{2}{*}{\multicolumn{2}{|c|}{ Model }} & \multicolumn{2}{|c|}{$\begin{array}{l}\text { Unstandardized } \\
\text { Coefficients }\end{array}$} & \multirow{2}{*}{$\begin{array}{l}\text { Standardized } \\
\text { Coefficients } \\
\text { Beta }\end{array}$} & \multirow[b]{2}{*}{$\mathrm{T}$} & \multirow[b]{2}{*}{ Sig. } & \multicolumn{2}{|c|}{$\begin{array}{l}\text { Collinearity } \\
\text { Statistics }\end{array}$} \\
\hline & & $B$ & Std. Error & & & & Tolerance & VIF \\
\hline \multirow[t]{3}{*}{1} & (Constant) & -1.536 & 1.655 & & -.928 & .384 & & \\
\hline & CR & -.740 & 1.709 & -.232 & -.433 & .678 & .348 & 2.872 \\
\hline & QR & 3.218 & 2.400 & .718 & 1.341 & .222 & .348 & 2.872 \\
\hline
\end{tabular}

a. Dependent Variable: PERUBAHAN LABA

Berdasarkan dai hasil olah data tabel 1 diperoleh nilai tolerance untuk variable CR sebesar $0.348>0.10$ dan QR sebesar $0.348>0.10$, nilai VIF untuk variable CR sebesar 2.872 
$<10.00$ dan nilai VIF untuk variable QR $2.872<10.00$. maka dapat disimpulkan bahwa tidak terjadi multikolinearitas.

\section{c. Uji autokorelasi}

Uji autokorelasi bertujuan untuk menguji apakah dalam suatu model regresi linar ada korelasi antara kesalahan pengganggu pada periode t dengan kesalahan pada periode t-1 (sebelumnya). Apabila terjadi korelasi menandakan bahwa terjadinya autokorelasi dalam penelitian ini uji autokorelasi menggunakan uji runt tes :

Tabel 2

Hasil uji autokorelasi

\begin{tabular}{|c|c|}
\hline \multicolumn{2}{|l|}{ Runs Test } \\
\hline & $\begin{array}{l}\text { Unstandar } \\
\text { dized } \\
\text { Residual }\end{array}$ \\
\hline Test Value ${ }^{\mathrm{a}}$ & -.24558 \\
\hline $\begin{array}{l}\text { Cases }<\text { Test } \\
\text { Value }\end{array}$ & 5 \\
\hline $\begin{array}{l}\text { Cases > } \\
\text { Value }\end{array}$ & 5 \\
\hline Total Cases & 10 \\
\hline $\begin{array}{l}\text { Number of Runs } \\
Z\end{array}$ & $\begin{array}{l}6 \\
.000\end{array}$ \\
\hline $\begin{array}{l}\text { Asymp. Sig. (2- } \\
\text { tailed) }\end{array}$ & 1.000 \\
\hline
\end{tabular}

a. Median

Berdasarkan hasil data tabel 2 didapatkan nilai asymp.sig(2-tailed) sebesar $1.000>0.05$ maka dapat disimpulkan bahwa tidak terdapat gejala pada autokorelasi.

\section{d. Uji heteroskadistisitas}

Uji heteroskedastisitas bertujuan untuk menguji apakah dalam model regresi terjadi ketidaksamaan variance dari residual satu pengamatan ke pengamatan yang lain. Untuk mengetahui adanya heteroskedastisitas adalah dengan melihat ada atau tidaknya pola tertentu pada grafik Scatterplot dengan ketentuan jika terdapat pola tertentu, maka terjadi heterokedastisitas. Namun jika tidak ada pola yang jelas dan titik-titik menyebar, maka tidak terjadi heteroskedastisitas.

\section{Hasil uji Heteroskedastisitas}


Scatterplot

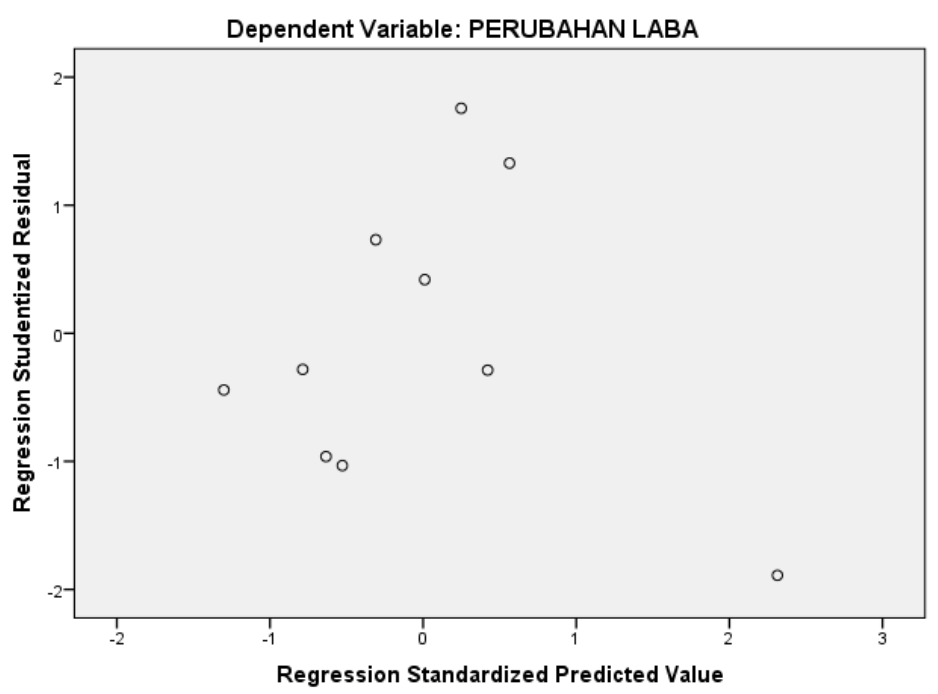

Dari hasil gambar spss diatas ditemukan bahwa data dalam penelitian tidak terjadi heteroskedastisitas. Hal ini terlihat pada uji scatter plot dimana sebaran titik-titik tidak membentuk pola tertentu, sehingga data dapat dikatakan tidak terjadi heteroskedastisitas.

\section{Hasil analisis regresi linear berganda}

Analisis regresi digunakan untuk mengukur kekuatan hubungan antara dua variabel atau lebih dan menunjukkan arah hubungan antara variabel dependen dengan variabel indepeden (Ghozali, 2011). Hasil analisis regresi linier berganda sebagai berikut :

Tabel 3

Hasil uji analisis regresi linear berganda

Coefficients $^{a}$

\begin{tabular}{|c|c|c|c|c|c|c|c|}
\hline \multirow[b]{2}{*}{ Model } & \multicolumn{2}{|c|}{$\begin{array}{l}\text { Unstandardized } \\
\text { Coefficients }\end{array}$} & \multirow{2}{*}{$\begin{array}{c}\begin{array}{c}\text { Standardiz } \\
\text { ed } \\
\text { Coefficients }\end{array} \\
\text { Beta } \\
\end{array}$} & \multirow[b]{2}{*}{$t$} & \multirow[b]{2}{*}{ Sig. } & \multicolumn{2}{|c|}{$\begin{array}{l}\text { Collinearity } \\
\text { Statistics }\end{array}$} \\
\hline & B & Std. Error & & & & $\begin{array}{l}\text { Toleran } \\
\text { ce }\end{array}$ & VIF \\
\hline $\begin{array}{cc}1 & \text { (Constan } \\
\text { t) }\end{array}$ & -1.536 & 1.655 & & -.928 & .384 & & \\
\hline CR & -.740 & 1.709 & -.232 & -.433 & .678 & .348 & 2.872 \\
\hline QR & 3.218 & 2.400 & .718 & 1.341 & .222 & 348 & 2.872 \\
\hline
\end{tabular}

a. Dependent Variable: PERUBAHAN LABA

Berdasarkan hasil olah data tabel 3 diatas maka Analisis regresi linear berganda :

$P L=\alpha+\beta 1 C R+\beta 2 Q R+e$

$P L=-1,536+-0,740 C R+3.2188 Q R$

\section{Uji Koefisien korelasi berganda}


Tabel 4

Hasil uji koefisien korelasi berganda

\begin{tabular}{|c|c|c|c|c|c|}
\hline $\mathrm{del}^{\text {Mo }}$ & $\mathrm{R}$ & $\begin{array}{c}\mathrm{R} \\
\text { Square }\end{array}$ & $\begin{array}{l}\text { Adjusted R } \\
\text { Square }\end{array}$ & \begin{tabular}{|lr} 
Std. & Error \\
of & the \\
Estimate & \\
\end{tabular} & $\begin{array}{l}\text { Durbin- } \\
\text { Watson }\end{array}$ \\
\hline 1 & $.548^{a}$ & .301 & .101 & .93308 & 1.522 \\
\hline
\end{tabular}

a. Predictors: (Constant), QR, CR

b. Dependent Variable: PERUBAHAN LABA

Berdasarkan hasil olah data tabel 4 nilai koefisien korelasi sebesar 0,548 artinya tingkat keeratan hubungan current ratio dan quick ratio terhadap perubhan perubahan laba pada PT. Indofood sukses makmur Tbk cukup sebesar 0,548.

\section{Uji koefisien determinasi}

Koefisien determinasi (R2) mengukur seberapa jauh kemampuan model dalam menerangkan variasi variabel dependen. Berdasarkan dari hasil uji Koefisien determinasi $R$ square yang telah dilakukan maka diperoleh hasil sebagai berikut:

\begin{tabular}{|c|c|c|c|c|c|}
\hline \multicolumn{6}{|c|}{$\begin{array}{c}\text { Tabel } 5 \\
\text { Hasil uji Determinasi } \\
\text { Model Summaryb }\end{array}$} \\
\hline $\begin{array}{l}\text { Mo } \\
\text { del }\end{array}$ & $\mathrm{R}$ & $\begin{array}{c}\mathrm{R} \\
\text { Square }\end{array}$ & $\begin{array}{l}\text { Adjusted R } \\
\text { Square }\end{array}$ & $\begin{array}{l}\text { Std. Error } \\
\text { of the } \\
\text { Estimate }\end{array}$ & $\begin{array}{l}\text { Durbin- } \\
\text { Watson }\end{array}$ \\
\hline 1 & $.548^{a}$ & .301 & .101 & .93308 & 1.522 \\
\hline
\end{tabular}

a. Predictors: (Constant), QR, CR

b. Dependent Variable: PERUBAHAN LABA

Berdasarkan hasil olah data tabel 5 koefisien determinasi $\left(R^{2}\right)$ menunjukan nilai sebesar 0.301 , hal ini berarti $30.1 \%$ variasi perubahan laba dapat dijelaskan oleh variasi dari ke dua variable independen (CR dan QR), sedangkan sisanya 69.9\% dipengaruhi oleh factor-faktor lain.

\section{Uji t}

Pengujian ini dilakukan untuk menguji hipotesis yang diajukan dalam penelitian atau untuk melihat pengaruh dari masing-masing variabel independen terhadap variabel dependen (Hertina,2019). 


\section{Tabel 6}

Hasil uji t

\section{Coefficients $^{\mathrm{a}}$}

\begin{tabular}{|c|c|c|c|c|c|c|c|c|}
\hline \multirow{2}{*}{\multicolumn{2}{|c|}{ Model }} & \multicolumn{2}{|c|}{$\begin{array}{c}\text { Unstandardized } \\
\text { Coefficients }\end{array}$} & \multirow{2}{*}{$\begin{array}{c}\text { Standardized } \\
\text { Coefficients } \\
\text { Beta } \\
\end{array}$} & \multirow[b]{2}{*}{$\mathrm{t}$} & \multirow[b]{2}{*}{ Sig. } & \multicolumn{2}{|c|}{ Collinearity Statistics } \\
\hline & & $\mathrm{B}$ & Std. Error & & & & Tolerance & VIF \\
\hline & (Constant) & -1.536 & 1.655 & & -.928 & .384 & & \\
\hline & $\mathrm{CR}$ & -.740 & 1.709 & -.232 & -.433 & .678 & .348 & 2.872 \\
\hline & QR & 3.218 & 2.400 & .718 & 1.341 & .222 & .348 & 2.872 \\
\hline
\end{tabular}

a. Dependent Variable: PERUBAHAN LABA

Berdasarkan hasil data pada tabel 6 diperoleh hasil perhitungan uji t beserta tingkat signifikan dengan penjelasan sebagai berikut:

a.) Uji t antara Current Ratio terhadap perubahan laba diperoleh tingkat signifikan variabel Current Ratio sebesar 0,678 > 0,05 berarti bahwa variabel Current Ratio tidak berpengaruh signifikan terhadap perubahan laba.

b.) Uji t antara Quick Ratio terhadap perubahan laba diperoleh tingkat signifikan variabel Quick Ratio sebesar 0,222 > 0,05 berarti bahwa variabel Quick Ratio tidak berpengaruh signifikan terhadap perubahan laba

Berdasarkan hasil uji t diatas pada hipotesis pertama menunujukan bahwa tidak terdapat pengaruh secara parsial antara current ratio (CR) terhadap perubahan laba.

Hasil penelitian ini tidak sejalan dengan hasil penelitian yang dilakukan oleh Annisa Erselina (2014) yang menunjukan hasil bahwa variabel current ratio berpengaruh secara signifikan terhadap perubahan laba.akan tetapi,hasil penelitian ini sejalan dengan hasil penelitian yang dilakuan oleh Gunawan dan Wahyuni (2013) yang menunjukan hasil bahwa current ratio tidak berpengaruh signifikan terhadap perubahan laba. hal ini disebabkan karena fungsi rasio lancar adalah untuk mengukur kemampuan pembayaran hutang perusahaan. maka penulis dapat menyimpulkan bahwa ada kesesuain antara hasil penelitian dengan teori,pendapat dan penelitian terdahulu yakni current ratio tidak memiliki pengaruh yang signifikan terhadap perubahan laba.

Berdasarkan hasil uji t diatas pada hipotesis kedua menunujukan bahwa tidak terdapat pengaruh secara parsial antara quick ratio (QR) terhadap perubahan laba.

Hasil penelitian ini sejalan dengan hasil penelitian yang dilakukan oleh Tika Nurmalasari (2011) menunjukkan hasil bahwa quick ratio tidak berpengaruh secara signifikan terhadap perubahan laba. Akan tetapi, penelitian ini tidak sejalan dengan penelitian yang dilakukan oleh Jiasti (2010) yang menunjukkan hasil bahwa quick ratio berpegaruh signifikan terhadap perubahan laba.

\section{Uji $f$}

Uji pada dasarnya menunjukan apakah semua variabel independen yang dimasukan dalam model yang diestimasi layak digunakan untuk menjelaskan pengaruh terhadap variabel dependen atau menguji apakah model yang digunakan sudah tepat atau tidak (Nugraha,2020). 


\section{Tabel 7}

Hasil uji F

ANOVA $^{\mathrm{a}}$

\begin{tabular}{|cc|c|c|c|c|c|}
\hline \multicolumn{1}{|c|}{ Model } & $\begin{array}{c}\text { Sum of } \\
\text { Squares }\end{array}$ & Df & Mean & Square & F & Sig. \\
\hline 1 & Regression & 2.620 & 2 & 1.310 & 1.504 & $.286^{\mathrm{b}}$ \\
& Residual & 6.094 & 7 & .871 & & \\
\multicolumn{1}{r|}{ Total } & 8.714 & 9 & & & \\
\hline
\end{tabular}

a. Dependent Variable: PERUBAHAN LABA

b. Predictors: (Constant), QR, CR

Berdasarkan hasil data tabel 7 menunjukan bahwa $F$ hitung sebesar 1,504 dengan tingkat signifikansi 0.286 berarti $0.286>0.05$ sehingga dapat disimpulkan bahwa tidak terdapat pengaruh signifikan terhdapat variable $\mathrm{CR}$ dan QR secara simultan terhadap perubahan laba.

Dari hasil uji $F$ diatas menunjukan bahwa secara bersamaan current ratio dan quick ratio tidak berpengaruh secara simultan terhadap perubahan laba pada PT. Akasha Wira Internasional Tbk. Hasil penelitian ini sejalan dengan hasil penelitian yang dilakukan oleh Andayani (2016) bahwan current ratio dan quick ratio tidak berpengaruh secara signifikan terhadap perubahan laba.

\section{KESIMPULAN DAN SARAN}

\section{Kesimpulan}

1. Berdasarkan hasil penelitian diatas current ratio tidak berpengaruh signifikan terhadap perubahan laba pada PT. Akasha Wira Internasional Tbk .

2. Berdasarkan hasil penelitian diatas quick ratio tidak berpengaruh signifikan terhadap perubahan laba pada PT. Akasha Wira Internasional Tbk .

3. Berdasarkan hasil penelitian diatas current ratio dan quick ratio tidak berpengaruh secara signifikan terhadap perubahan laba pada PT. Akasha Wira Internasional Tbk.

\section{Saran}

Berdasarkan hasil penelitian terdapat beberapa saran untuk penelitian selanjutnya yaitu :1) Bagi manajemen perusahaan,evaluasi secara terus menerus sebaiknya dilakukan perusahaan untuk menilai kinerjanya melalui analisis rasio keuangan sehingga dapat diketahui adanya kenaikan atau penurunan dari laba perusahaan. 2) Bagi peneliti selanjutnya dapat dilakukan dengan menambah atau menggunakan variabel lain seperti net profit margin, gross profit margin, selain itu memperbanyak sampel penelitian agar hasil penelitian selanjutnya menjadi lebih tepat dan akurat.

\section{DAFTAR PUSTAKA}

Erselina, A. 2014. Analisis Prediksian Rasio Keuangan Terhadap Perubahan Laba pada Perusahaan Property dan Real Estate yang Terdaftar Di Bursa Efek Indonesia (BEI) Tahun 2008-2011. JOM FEKON 1(2): 11-13.

Fahmi, Irham. 2012. Analisis Laporan Keuangan. Alfabeta: Bandung.

Ghozali, I. 2016. Aplikasi Analisis Multivariete dengan Program SPSS. Edisi Kedelapan. Badan Penerbit Universitas Diponegoro. Semarang. 
Ghozali. 2011. Aplikasi Analisis Multivariate dengan Program SPSS. Edisi Ketiga. Universitas Diponegoro. Semarang

Gunawan, A dan S. Wahyuni. 2013. Pengaruh Rasio Keuangan Terhadap Pertumbuhan Laba Pada Perusahaan Perdagangan Di Indonesia. Jurnal Manajemen \& Bisnis 13(01): 63- 84.

Hanafi, Mamduh M dan Halim A. 2007. Analisis Laporan Keuangan, Edisi 3. UPP YPKN, YogyakartaHanafi, Mamduh M dan Halim A. 2007. Analisis Laporan Keuangan, Edisi 3. UPP YPKN, Yogyakarta

Harahap, Sofyan Syafri. 2015. Analisis Kritis Atas Laporan Keuangan. Edisi 1-10. Jakarta: Rajawali Pers.

Hertina, D., \& Hidayat, M. B. H. (2019). Pengaruh Likuiditas, Solvabilitas dan Nilai Pasar Terhadap Return Saham. JEMPER (Jurnal Ekonomi Manajemen Perbankan), 1(1), 4348.

Hery. 2015. Analisis Laporan Keuangan. PT Buku Seru: Yogyakarta. -----. 2016. Analisis Laporan Keuangan-Integrated and Comprehensive Edition. Jakarta: PT. Grasindo.

Jiasti, F. D. 2010. Analisis Pengaruh Current Ratio, Quick Ratio, Receivable Turn Over, Dan Cash Turn Over Terhadap Laba Usaha (Koperasi Kopersemar Periode Tahun 2007-2009). Skripsi. Universitas Diponegoro. Semarang.

Kasmir. 2017. Analisis Laporan Keuangan. Edisi Satu. Cetakan kesepuluh. PT RajaGrafindo Persada. Jakarta.

Nurmalasari, T. 2011. Analisis Pengaruh Rasio Keuangan Terhadap Perubahan Laba pada Perusahaan Manufaktur yang Terdaftar di Bursa Efek Indonesia (BEI). Jakarta: Universitas Gunadarma.

Nugraha, N. M., Puspitasari, D. M., \& Amalia, S. (2020). The Effect of Financial Ratio Factors on the Percentage of Income Increasing of Automotive Companies in Indonesia. International Journal of Psychosocial Rehabilitation, 24(1), 2539-2545. https://doi.org/10.37200/IJPR/V24I1/PR200366

Riana, Devi, dan Diyani, Lucia Ari. 2016.“ Pengaruh Rasio Keuangan dalam Memprediksi Perubahan Laba pada Industri Farmasi (Studi Kasus pada BEI Tahun 2011-2014)”, Jurnal Online Insan Akuntansi, Vol. 1, No. 1, 16-42 E-ISSN: 2528-0163, Juni, Akademi Akuntansi Bina Insani, Bekasi Timur.

Sa'diyah, H. dan M. Kemarauwana. 2015. Pengaruh Current Ratio, Debt to Equity Ratio, Total Asset Turn Over dan Net Profit Margin Terhadap Perubahan Laba di PT Skill Indotimur Agung Surabaya Tahun 2002-2011. Ebis. 7(1):75-84.

Septiawan, A. N. 2014. Analisis CR, DER, TATO, GPM, dan ROE Terhadap Perubahan Laba Pada Perusahaan Manufaktur yang Terdaftar di Bursa Efek Indonesia (BEI). Skripsi. Fakultas Ekonomi Dan Bisnis Universitas Hasanuddin. Makassar.

Sugiyono. 2016. Metode Penelitian Kuantitatif, Kualitatifdan R\&D. bandung: Alfabeta. 